\title{
Peri-Conceptional undernutrition in twin bearing ewes: Effect on early fetal growth and birth weight
}

\section{Desnutrición peri-concepcional en ovejas con gestación gemelar: Efecto sobre el crecimiento fetal temprano y peso al nacimiento}

\author{
Ricardo Vicente-Pérez ${ }^{1}$, Yolanda Osorio-Marín ${ }^{1}$, María A. López-Baca ${ }^{1}$, Leonel Avendaño-Reyes ${ }^{1}$, Abelardo \\ Correa-Calderón ${ }^{1}$, M. Mellado ${ }^{2}$, Ana L. Lara-Rivera ${ }^{1}$, Cesar A. Meza-Herrera ${ }^{3}$, Ulises Macías-Cruz ${ }^{1 *}$ \\ ${ }^{1}$ Instituto de Ciencias Agrícolas, Universidad Autónoma de Baja California, Ejido Nuevo León s/n, CP. 21705, Mexicali, B.C., \\ México. \\ ${ }^{2}$ Departamento de Nutrición Animal, Universidad Autónoma Agraria Antonio Narro, Saltillo, Coahuila, México. \\ ${ }^{3}$ Unidad Regional Universitaria de Zonas Áridas, Universidad Autónoma Chapingo, Bermejillo, Durango, México. \\ ${ }^{*}$ Corresponding author: ulisesmacias1988@hotmail.com
}

Scientific article received: March 09, 2017 accepted: June 08, 2017

\begin{abstract}
A total of 48 Katahdin $\times$ Pelibuey multiparous ewes were used to evaluate the effect of nutritional restriction $(40 \%)$ before ( $30 \mathrm{~d}, \mathrm{RT})$, after $(50 \mathrm{~d}$, TR) or both periods ( $80 \mathrm{~d}, \mathrm{RR})$ compared with a control group on maternal body status, early fetal growth and lamb birth weights. Only twin bearing ewes were selected at $d 50$ of pregnancy for fetal measurements by ultrasonography and record of birth weight. Compared with control ewes, lower ( $p<0.05$ ) weight and body condition score had RT and RR ewes at mating time, likewise, TR and RR ewes at d 50 post-conception. There were mainly differences between fetuses from control and RT ewes, being higher $(p<0.05)$ the vesicular, abdominal and fetal area, as well as crown-rump length and birth weight for RT fetuses. In conclusion, preconception undernutrition positively altered the early fetal growth and lamb birth weights in hair ewes pregnant with twins.
\end{abstract}

Key words: Fetal growth, cotyledons, twin pregnancy, crown-rump length, nutritional restriction

RESUMEN. Se usaron 48 ovejas multíparas Katahdin x Pelibuey para evaluar el efecto del $40 \%$ de restricción nutricional antes ( $30 \mathrm{~d}, \mathrm{RT})$, después ( $50 \mathrm{~d}, \mathrm{TR})$ o antes y después de la concepción ( $80 \mathrm{~d}, \mathrm{RR})$, comparado con un grupo testigo sobre el estado corporal materno, crecimiento fetal temprano y peso al nacimiento de las crías. Solo ovejas con preñez gemelar fueron seleccionadas al día 50 post-monta para mediciones fetales por ultrasonografía y registro de peso al nacimiento. Las ovejas RT y RR tuvieron menor $(p<0.05)$ peso y condición corporal al empadre, mientras que las ovejas TR y RR a los 50 días post-concepción tuvieron menor peso que las ovejas de los otros tratamientos. Se observaron diferencias entre fetos de ovejas testigo y RT, siendo mayor $(p<0.05)$ el área vesicular, abdominal y fetal, además de la longitud cráneo-caudal y los pesos al nacimiento en fetos de ovejas RT. La desnutrición pre-concepción alteró de forma positiva el crecimiento fetal temprano y el peso al nacimiento de las crías en ovejas de pelo con preñez gemelar.

Palabras clave: Crecimiento fetal, cotiledones, gemelos, longitud cráneo-caudal, restricción nutricional

\section{INTRODUCTION}

The productive, reproductive and immunological capacity of the sheep throughout their postnatal life has a direct relation with the uterine environment in which they develop during the gestation. The nutritional status of pregnant ewes is the main factor related to alterations in the uterine environment, and fetal development and growth (Martin et al. 2004). In this sense, appropriate and strategic feeding before and during critical times of pregnancy ensures a correct de- 
velopment of the offspring in their pre- and postnatal life (Lassoued et al. 2004, Corner-Thomas et al. 2014). Maternal nutritional restriction around peri-conception has been related to alterations in the fetal growth during the last third of pregnancy (Bloomfield et al. 2004, Rumball et al. 2009), as well as post-natal problems of diseases, slow growth and low fertility in young and adult sheep (Cleal et al., 2007). Maternal peri-conceptional malnutrition has also been reported to alter fetal growth trajectory, but not birth weight (Bloomfield et al. 2013). The foregoing is due to the fact that malnutrition of the ewes during conception alters fetal programming in the early embryonic stage, which confers on the fetus physiological and metabolic adaptations that favor its survival under limited nutrient availability scenarios (Morrison et al. 2010). Although, the development of these adaptations are not completely beneficial, considering that they affect the functional competence of offsprings both in pre- and post-birth (Fleming et al. 2012).

Most reports on peri-conceptional nutritional restriction have been conducted to evaluate the long-term effects on the fetal development, since finding alterations in the fetal growth and development during the last third of pregnancy is more likely, due to the fact that around $80 \%$ of the growth of the product occurs at this stage (Oliver et al. 2005, Morrison et al. 2010, Bloomfield et al. 2013). However, there is no evidence suggesting that the negative impact of peri-conceptional nutritional restriction can be reflected in short term, depending of the grade and time of undernutrition pre- and post-conception. In this regard, Sejian et al. (2010) noted a decrease in the vesicular development in Malpura ewes, and Muñoz et al. (2008) found lower cranial and abdominal diameter in fetuses from Greyface ewe during the beginning of the second third of gestation, both findings as result of the peri-conceptional undernutrition. Although there are also studies that reported no alterations in fetal growth at the end of the first third of gestation in Australian Merino (MacLaughlin et al. 2005) and Rahnani (Abdel-Mageed et al. 2015) ewes when they were underfed around the mating time. The number of fetuses and the period of malnutrition before and/or after conception could explain part of the inconsistencies found. In this regard, Rumball et al. (2009) found that undernutrition preand post-conception have different effects on fetal growth, metabolism and endocrine status during the last third of gestation. Similarly, MacLaughlin et al. (2005) and Rumball et al. (2008) found that long-term malnutrition around conception promotes different fetal growth and development, depending on the pregnancy type (single or twin). It is known that the availability of food in extensive systems depends on the rainy season; therefore, sheep often face problems of poor nutrition. Therefore, the objective of this study was to compare different periods of undernutrition around conception, with a control in relation to maternal body status, early fetal development and birth weight of lambs in twin bearing hairsheep ewes.

\section{MATERIALS AND METHODS}

\section{Animals and Treatments}

The study was conducted in the autumn of 2014 within the facilities of the Sheep Experimental Unit of the Institute of Agricultural Sciences, UABC, located in the Mexicali Valley, Baja California, Mexico (32.8 $\mathrm{NL}$ and $115^{\circ} \mathrm{WL}$ ). The experiment was developed using 48 multiparous Katahdin $x$ Pelibuey ewes (live weight $[\mathrm{LW}]=50.3 \pm 0.6 \mathrm{~kg}$, body condition score $[\mathrm{BCS}]=3.0 \pm 0.1$ units and number of lambing $=3$ to 4 ), which were assigned under a randomized complete block design to one of four treatments $(n=12)$, using LW as blocking factor. Treatments consisted in feeding the ewes with: 1) $100 \%$ of nutritional requirements 30 days before and $50 \mathrm{~d}$ after mating time (control), 2) 60 $\%$ of nutritional requirements during the 30 days before mating time (RT), 3) $60 \%$ of nutritional requirements during the 50 days after mating time (TR) and 4) $60 \%$ of nutritional requirements during the 30 days before and $50 \mathrm{~d}$ after mating time (RR). Diets offered before and after the mating time were the same for all treatments and the only difference was the daily amount of dry matter (DM) offered 
based on the ewe LW (NRC 2007). Thus, the formulation of the diet to meet maintenance requirements in the pre-mating period was the following: metabolizable energy $(\mathrm{ME})=1.9 \mathrm{Mcal} \mathrm{kg}^{-1}$ of (DM), crude protein (CP) $=81 \mathrm{~g} \mathrm{~kg}^{-1}$ of DM, rumen degradable crude protein (RDCP) $=69 \mathrm{~g} \mathrm{~kg}^{-1}$ of $\mathrm{DM}, \mathrm{Ca}=2.4 \mathrm{~g} \mathrm{~kg}^{-1}$ of $\mathrm{DM}$ and $\mathrm{P}=1.8 \mathrm{~g} \mathrm{~kg}^{-1}$ of DM, while for ewes in early gestation with two fetuses in the post-mating period it was as follows: $\mathrm{ME}=1.9 \mathrm{Mcal} \mathrm{kg}{ }^{-1}$ of $\mathrm{DM}, \mathrm{CP}=8.7 \mathrm{~g} \mathrm{~kg}^{-1}$ of $\mathrm{DM}, \mathrm{RDCP}=69 \mathrm{~g} \mathrm{~kg}^{-1}$ of $\mathrm{DM}, \mathrm{Ca}=4.1 \mathrm{~g} \mathrm{~kg}^{-1}$ of $D M$ and $P=2.8 \mathrm{~g} \mathrm{~kg}^{-1}$ of DM. Figure 1 presents the feeding schemes for each treatment based on the amount of DM offered; given the slight variation indicated in the NRC (2007) for nutritional requirements before and after mating time in sheep, it was decided to formulate two diets, one for each experimental stage. After completing the phase in which the dietary treatments were offered, all the ewes were fed ad libitum with the post-mating diet until the day 100 of gestation, and then the diet was changed between day 101 of gestation and lambing to cover nutritional requirements for ewes with twin gestation during the last third $\left(\mathrm{ME}=2.4 \mathrm{Mcal} \mathrm{kg}^{-1}\right.$ of $\mathrm{DM}, \mathrm{CP}=11.2 \mathrm{~g} \mathrm{~kg}^{-1}$ of $\mathrm{DM}, \mathrm{RDCP}=86 \mathrm{~g} \mathrm{~kg}^{-1}$ of $\mathrm{DM}, \mathrm{Ca}=5.0 \mathrm{~g} \mathrm{~kg}^{-1}$ of $\mathrm{DM}$ and $\mathrm{P}=2.9 \mathrm{~g} \mathrm{~kg}^{-1}$ of DM; NRC 2007). Table 1 shows ingredients and chemical composition of diets.

\section{Experimental Management}

All ewes were treated with $1.0 \mathrm{~mL}$ of ADE Vitamins (Vidafluid ${ }^{\circledR}$ ), $5.0 \mathrm{~mL}$ of $B$ complex (Complejo- $\left.{ }^{\circledR}\right)$ ) and $1.0 \mathrm{~mL}$ of dewormer (Virbamec ${ }^{R}$ ) 15 days prior to the beginning of the experiment. In this same period, the ewes were adapted to the pre-mating diet, which contained chopped hay of Sudan grass (Sorghum $\mathrm{x}$ drummondii) and alfalfa (Medicago sativa L.). In the adaptation period, ewes were housed in two pens; and then, at the beginning of the experiment, they were housed in four pens of $25 \mathrm{~m}^{2}$, one per treatment. Each pen had two water troughs, galvanized sheet roof $\left(12 \mathrm{~m}^{2}\right)$ and enough space in the trough for all ewes to consume the diet at the same time and reduce competition. Food was offered every day in the morning $(07: 00 \mathrm{~h}, 60 \%)$ and in the afternoon (17:00 h, $40 \%)$, according to the treatments (Figure 1). The ewes were weighed individually every $10 \mathrm{~d}$ to adjust the amount of feed offered. The feed rejected per pen was also recorded every day to calculate the feed intake per pen. Only in the pens of control ewes ( $4.8 \%$ pre-mating period and $3.7 \%$ post-mating period from the $100 \%$ feed offered) and TR (4.3\% pre-mating period and $0 \%$ post-mating period from $100 \%$ feed offered) was observed feed rejected during the study period. The water was offered freely, and the health status of ewes was checked visually every day.

Also, an estrus synchronization protocol was applied in combination with a controlled mating system to match the end of the pre-mating period and the beginning of the post-mating period in all ewes. The protocol consisted of introducing, intravaginally, sponges impregnated with $20 \mathrm{mg}$ of fluorogestone acetate (Chronogest ${ }^{\circledR} \quad$ CR) for 10 days (day 11 to 1 pre-mating) and, $24 \mathrm{~h}$ prior to remove the sponge, $300 \mathrm{IU}$ ewe $^{-1}$ of equine chorionic gonadotrophin (Folligon ${ }^{\circledR}$ ) were applied i.m.. Between 12 and $36 \mathrm{~h}$ after the end of the protocol, ewes were exposed to white Dorper breed rams every $3 \mathrm{~h}$ for $30 \mathrm{~min}$ to detect oestrus activity. Each ewe received two matings, one at the time of estrus detection and the other $12 \mathrm{~h}$ later. In general, six rams of proven fertility were used; 100 $\%$ of the ewes responded to hormonal treatment and were mated.

\section{Measurements in Ewes and Fetuses}

The LW and BCS of the ewes were recorded individually at day $-30,0$ and 50 of the experimental period. The LW was determined using a livestock electronic scale, while BCS was evaluated on the 5-point scale (Russell et al. 1969). With this information, LW and BCS changes were calculated in the following periods: pre-mating, first third of gestation and overall period.

At the end of the experimental period (day 50 post-mating), pregnancy diagnosis and fetal count by ultrasonography was performed. In ewes pregnant with twins, measurements of vesicle, fetus and 


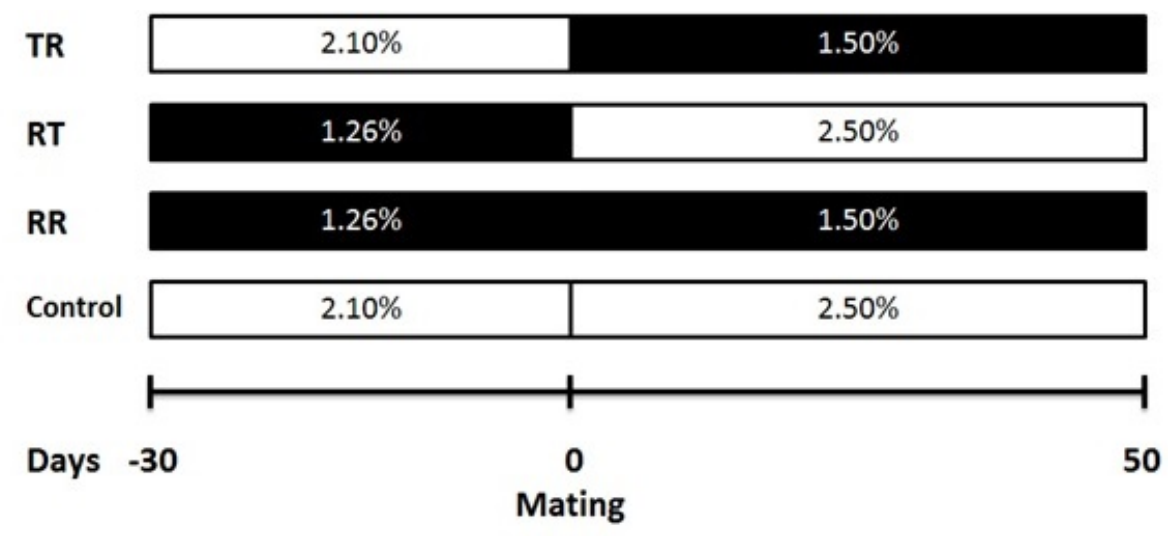

Figure 1. Feeding scheme based on the live weight percentage for ewes fed $100 \%$ of nutritional requirements (control), or with nutritional restriction of $40 \%$ of nutritional requirements during the pre-mating (RT), first third of gestation (TR) or in both periods (RR). The amount of dry matter offered based on live weight in control ewe was calculated according to NRC (2007).

Table 1. Ingredients and chemical composition of the experimental diets offered during the pre-mating $(30 \mathrm{~d})$, post-conception (first 100 days) and late gestation (last $50 \mathrm{~d}$ ) periods.

\begin{tabular}{|c|c|c|c|}
\hline Ingredient & Pre-mating & Post-conception & Late Gestation \\
\hline \multicolumn{4}{|c|}{ Ingredients $\left(\mathrm{g} \mathrm{kg}^{-1}\right.$ of $\left.\mathrm{DM}\right)$} \\
\hline Sudan hay & 850 & 800 & - \\
\hline Alfalfa hay & 150 & 200 & 160 \\
\hline Wheat straw & - & - & 305 \\
\hline Ground wheat & - & - & 425 \\
\hline Soybean meal & - & - & 45 \\
\hline Molasses & - & - & 45 \\
\hline Vitamin-mineral premix & - & - & 5 \\
\hline Limestone & - & - & 6 \\
\hline Orthophosphate & - & - & 6 \\
\hline Common salt & - & - & 3 \\
\hline \multicolumn{4}{|c|}{ Chemical composition } \\
\hline Dry matter $\left(\mathrm{g} \mathrm{kg}^{-1}\right)$ & 922 & 923 & 908 \\
\hline Organic matter $\left(\mathrm{g} \mathrm{kg}^{-1}\right.$ of DM) & 865 & 862 & 901 \\
\hline Crude protein $\left(\mathrm{g} \mathrm{kg}^{-1}\right.$ of DM) & 85 & 93 & 121 \\
\hline Ethereal extract $\left(\mathrm{g} \mathrm{kg}^{-1}\right.$ of DM) & 12 & 12 & 31 \\
\hline Neutral detergent fiber $\left(\mathrm{g} \mathrm{kg}^{-1}\right.$ of $\left.\mathrm{DM}\right)$ & 613 & 642 & 435 \\
\hline TDN $\left(\mathrm{g} \mathrm{kg}^{-1}\right.$ of DM) & 560 & 543 & 662 \\
\hline DE (Mcal kg ${ }^{-1}$ of DM) & 2.4 & 2.4 & 2.9 \\
\hline ME (Mcal kg ${ }^{-1}$ of DM) & 2.0 & 2.0 & 2.4 \\
\hline
\end{tabular}

cotyledons were performed using the methodology described by Ali et al. (2007). In vesicle and cotyledons, length, width and area were measured; while crown-rump length, fetal area, occipital-nasal length, frontal length, head area, as well as abdominal length, width and area were measured in fetuses. Images of one fetus and six cotyledons per ewe were taken to make the measurements and to ensure the care indicated by Muñoz et al. (2008), who suggest performing the evaluation of one fetus to not expose them for more than $3 \mathrm{~min}$ to the ultrasound waves because this affect their development. An ultrasound equipped with a $3.5 / 7.5 \mathrm{MHz}$ multifrequential rectal transducer (LCD Ultrasound Scanner, Draminski Animal profi) was used for the measurements. The ewes were under continuous 
observation between days 144 and 150 of gestation to ensure that all lambs were weighed before consuming colostrum and after the mother cleaned them. Thus, lambs were identified and then birth weight and sex were recorded individually.

\section{Statistical Analysis}

Only information from the ewes pregnant with twins was used. All statistical analyzes were performed using the statistical package SAS (2004). Data collected from each variable were analyzed using the UNIVARIATE procedure to verify normality through the Shapiro-Wilk and KolmogorovSmirnov tests. The data of variables with absence of normality were transformed with square root to obtain normality. Subsequently, variables of LW, BCS and fetal measurements were subjected to analysis of variances under a completely randomized design using GLM procedure. Models had to treatment as fixed effect and to initial LW as covariable. In the case of lamb birth weight, the analysis was developed using the MIXED procedure and the model considered the fixed effect of treatment and nesting of breeding within the mother as a random effect. The means were compared with the Dunnett's test, considering differences between control and each treated group at $p \leq 0.05$.

\section{RESULTS}

The control ewes presented similar $(p>0.05)$ $\operatorname{LW}(47.8 \pm 0.8 \mathrm{~kg})$ and BCS (3.0 \pm 0.1 units) than ewes treated with any nutritional restriction period at the beginning of the experiment (day 30). However, RT, TR and RR ewes compared to control ewes lost $(p<0.05)$ LW and BCS in nutritional restriction periods (Table 2). Therefore, the control ewes had higher $(p<0.05)$ LW and BCS than RT and RR ewes at mating, as well as than TR and RR ewes at $50 \mathrm{~d}$ post-lambing (Figure 2).

Some means of vesicular and fetal measurements showed to be different between control and RT ewes (Table 3); being, in RT ewes, higher ( $p<$ $0.05)$ vesicular length $(60.5 \mathrm{vs} .77 .7 \pm 3.2 \mathrm{~mm}$ ) and area (20 vs. $26.8 \pm 1.6 \mathrm{~cm}^{2}$ ), crown-rump length
(54.2 vs. $60.1 \pm 1.5 \mathrm{~mm}$ ), total fetal area (6.8 vs. $9.7 \pm 0.9 \mathrm{~cm}^{2}$ ) and abdominal area (4.2 vs. 5.2 $\left.\pm 0.2 \mathrm{~cm}^{2}\right)$. Except for occipital-nasal length, the means of vesicular and fetal measurements did not differ $(p>0.05)$ between control ewes and those treated as TR and RR. Fetuses from control ewes had greater $(p<0.05)$ occipital-nasal length than fetuses from RR ewes in $17 \%$. The development of placentomes in control ewes was similar ( $p>0.05)$ to that observed in RT, TR and RR ewes.

The weights at birth were higher $(p<0.05)$ in lambs from RT ewes than in lambs from control ewes ( 2.9 vs. $3.8 \pm 0.2 \mathrm{~kg}$ ), which did not show differences $(p>0.05)$ with respect to lambs from TR and RR ewes (Figure 3).

\section{DISCUSSION}

There is sufficient evidence of the negative impact of nutritional restriction on the body status of ewes during the pre-mating period (MacLaughlin et al. 2005, Grazul-Bilska et al. 2013) and first third of gestation (Cleal et al. 2007); situation that is explained by the mobilization of body reserves, as a strategy to compensate for dietary nutritional deficits (NRC 2007, Robertson et al. 2015). There are also reports indicating that ewes fed below the nutritional requirements for maintenance and production may quickly recover their normal body status when they are fed with $100 \%$ of nutritional requirements or ad libitum with a balanced diet (Belkacemi et al. 2010). This explains, in general terms, the changes in LW and BC observed in the TR and RT ewes.

In RR ewes, it was observed that from 100 $\%$ of weight lost during the experiment, $60 \%$ was lost in the $30 \mathrm{~d}$ pre-conception and only $40 \%$ in the $50 \mathrm{~d}$ post-conception. This suggests that hair breed ewes have the ability to activate their adaptive mechanisms in chronic nutritional restriction scenarios, possibly of physiological and metabolic types. An immediate response from these ewes it is the mobilization of their body reserves to compensate for the nutritional deficit; however, when the period of malnutrition lengthens, they present ad- 
Vicente-Perez et al.

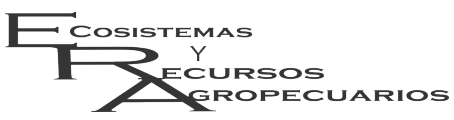

Early fetal growth in underfed ewe

Ecosist. Recur. Agropec.

4(12):419-429,2017

Table 2. Changes in live weight and body condition score during the pre-mating, first third of gestation or both periods by effect of the peri-conceptional nutritional restriction in hair ewes.

\begin{tabular}{|c|c|c|c|c|c|c|}
\hline \multirow[t]{2}{*}{ Items } & \multicolumn{4}{|c|}{ Treatments } & \multirow[t]{2}{*}{ SEM } & \multirow[t]{2}{*}{ P-Value } \\
\hline & Control & RT & TR & RR & & \\
\hline \multicolumn{7}{|l|}{ Change of live weight (kg) } \\
\hline Day -30 to mating & 0.5 & $-3.1 * *$ & 1.1 & $-3.4 *$ & 0.5 & $<0.01$ \\
\hline Day 1 to 50 of gestation & 0.7 & $4.4^{* *}$ & $-5.5^{* *}$ & $-2.2^{* *}$ & 0.5 & $<0.01$ \\
\hline Day -30 to 50 of gestation & 1.2 & 1.3 & $-4.4 * *$ & $-5.7 * *$ & 0.9 & $<0.01$ \\
\hline \multicolumn{7}{|c|}{ Change of body condition (Units) } \\
\hline Day -30 to mating & 0.05 & $-0.3 *$ & 0.05 & $-0.3^{*}$ & 0.08 & $<0.01$ \\
\hline Day 1 to 50 of gestation & 0.1 & $0.3^{*}$ & $-0.5^{* *}$ & $-0.3^{*}$ & 0.09 & $<0.01$ \\
\hline Day -30 to 50 of gestation & 0.1 & -0.02 & $-0.5 * *$ & $-0.6 * *$ & 0.09 & $<0.01$ \\
\hline
\end{tabular}

Feeding at $100 \%$ of nutritional requirements (control), or with nutritional restriction of 40 $\%$ of nutritional requirements during the pre-mating (RT), first third of gestation (TR) or in both periods (RR). Differences between control group and any group treated with nutritional restriction are indicated with $*(\mathrm{p}<0.05)$ and $* *(\mathrm{p}<0.01)$.

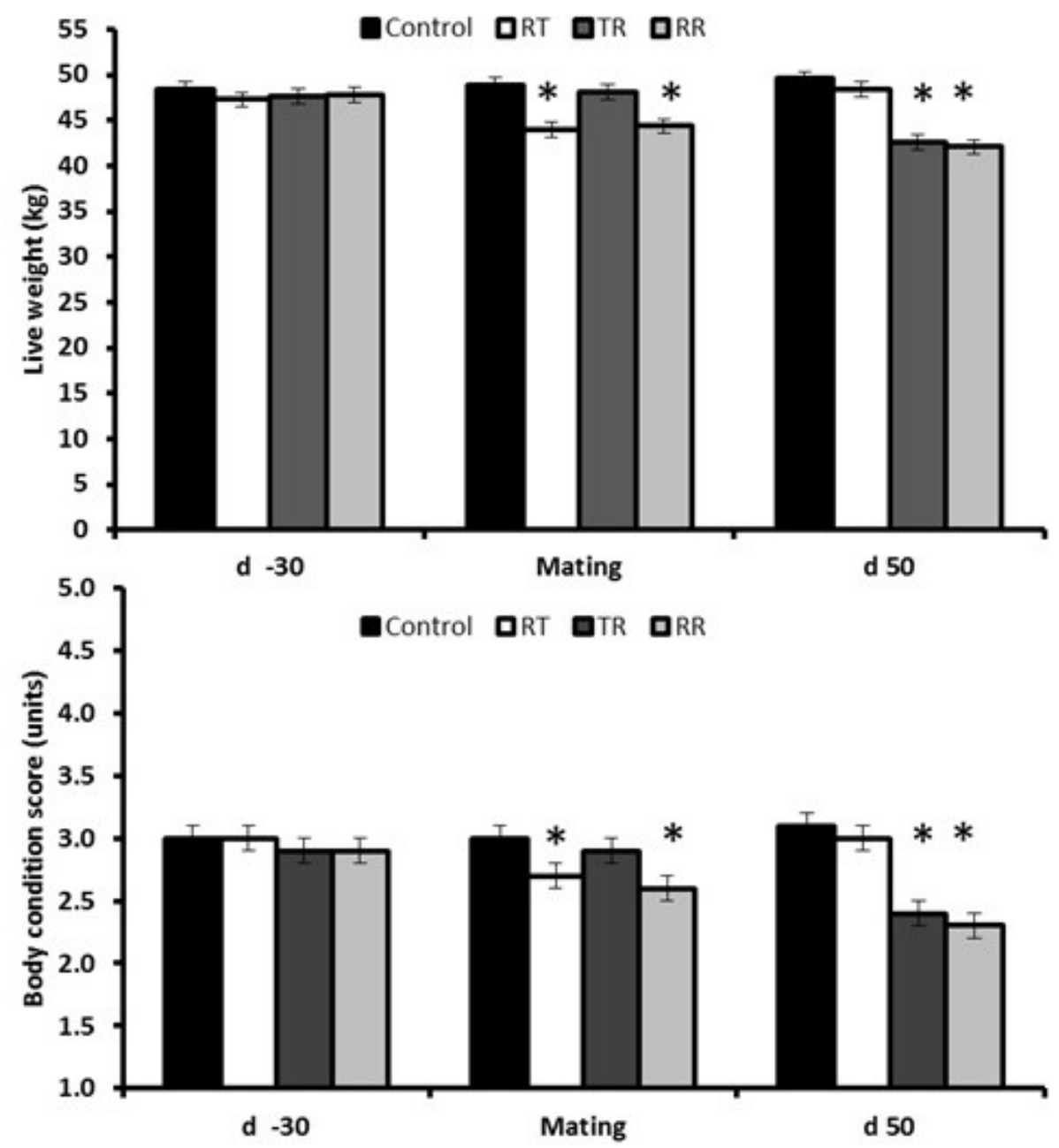

Figure 2. Live weight and body condition score in hair ewes fed $100 \%$ nutritional requirements (control), or with $40 \%$ of nutritional restriction before (RT), after (TR) or before and after $(\mathrm{RR})$ of mating. (* Indicate differences regarding the control at $\mathrm{p} \leq 0.05$ ). 
Table 3. Vesicular, fetal and cotyledonary development by effect of the periconceptional nutritional restriction in hair ewes at day 50 post-conception.

\begin{tabular}{|c|c|c|c|c|c|c|}
\hline \multirow[t]{2}{*}{ Items } & \multicolumn{4}{|c|}{ Treatments } & \multirow[t]{2}{*}{ SEM } & \multirow[t]{2}{*}{ P-Value } \\
\hline & Control & RT & TR & RR & & \\
\hline \multicolumn{7}{|l|}{ Vesicle } \\
\hline Length (mm) & 60.5 & $77.7^{*}$ & 64.6 & 62.3 & 3.2 & 0.03 \\
\hline Width (mm) & 39.9 & 43.4 & 41.8 & 44.7 & 3.2 & 0.54 \\
\hline Area $\left(\mathrm{cm}^{2}\right)$ & 20.0 & $26.8^{*}$ & 20.2 & 20.2 & 1.6 & 0.04 \\
\hline \multicolumn{7}{|l|}{ Fetus } \\
\hline Crown-rump length (mm) & 54.2 & $60.1^{*}$ & 55.7 & 57.3 & 1.5 & 0.05 \\
\hline Fetus area $\left(\mathrm{cm}^{2}\right)$ & 6.8 & $9.7^{*}$ & 6.7 & 7.4 & 0.9 & 0.03 \\
\hline Occipital-nasal length & 23.1 & 22.1 & 22.8 & $19.0^{*}$ & 1.3 & 0.04 \\
\hline Front length (mm) & 17.2 & 17.0 & 17.3 & 16.2 & 1.1 & 0.62 \\
\hline Head area $\left(\mathrm{cm}^{2}\right)$ & 2.3 & 2.6 & 2.7 & 2.4 & 0.4 & 0.93 \\
\hline Abdomen length (mm) & 28.7 & 32.9 & 29.5 & 30.6 & 1.8 & 0.38 \\
\hline Abdomen width (mm) & 15.9 & 17.0 & 16.9 & 17.4 & 0.7 & 0.60 \\
\hline Abdomen area $\left(\mathrm{cm}^{2}\right)$ & 4.2 & $5.2^{*}$ & 4.1 & 3.9 & 0.2 & 0.04 \\
\hline \multicolumn{7}{|l|}{ Cotyledons } \\
\hline Length $(\mathrm{mm})$ & 19.0 & 17.7 & 17.2 & 18.6 & 1.2 & 0.34 \\
\hline Width $(\mathrm{mm})$ & 22.0 & 20.5 & 20.4 & 22.4 & 1.2 & 0.21 \\
\hline Area $\left(\mathrm{cm}^{2}\right)$ & 3.0 & 2.5 & 2.6 & 2.9 & 0.3 & 0.37 \\
\hline
\end{tabular}

Feeding at $100 \%$ of nutritional requirements (control), or with nutritional restriction of $40 \%$ of nutritional requirements during the pre-mating (RT), first third of gestation (TR) or in both periods (RR). Differences between control group and any group treated with nutritional restriction are indicated with $*(\mathrm{p}<0.05)$ and $* *(\mathrm{p}<0.01)$.

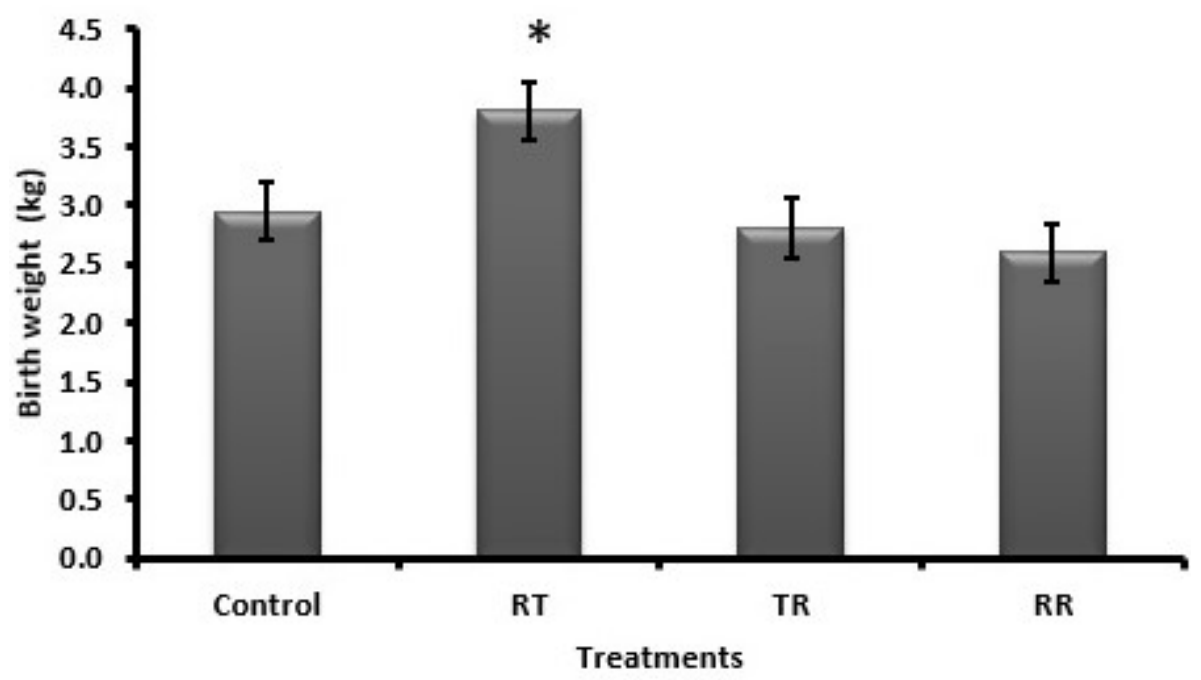

Figure 3. Birth weight in lambs of twin lambing born from hair ewes fed $100 \%$ nutritional requirements (control), or with $40 \%$ nutritional restriction before (RT), after (TR) or before and after (RR) of mating. (* Indicate differences regarding the control at $\mathrm{p} \leq 0.05$ ).

justments that allow them to decrease loss of body reserves, which make a more efficient use of the available energy (Chillard et al. 1998). This study did not evaluate metabolites and metabolic hormones, but some studies indicate that ewes with chronic nutritional restriction may activate adaptive mechanisms such as: decreased levels of leptin, which motivate appetite centers to decrease energy delivery; reduction of energy use and increase in nitrogen recycling to favor the feed efficiency (Boland et al. 2001); and increase of the rate of mastication and decrease of the rate of passage to increase feed digestibility and synthesis of protein and energetic compounds by rumen microflora (Galvani et 
al. 2010).

Result showed that, in hair breed ewes pregnant with twins, fetal growth at 50 days of gestation was positively altered by the effect of severe nutritional restriction during the 30 days prior to mating time. Although these alterations in fetal growth were not evidenced when the nutritional restriction occurred during the first third of gestation, or it was chronic from 30 days before mating until 50 days after conception. In this regard, Jaquiery et al. (2009) mention that chronic malnutrition prior to conception may lead to low fetal growth during the gestation of single fetuses due to failures in the presence of insulin resistance, which is a normal metabolic adaptation mechanism developed by pregnant ewes to provide the greatest amount of nutrients to the fetus. For its part, Pisani et al. (2008) indicate that ewes with signs of severe malnutrition during the conception present alterations in the transcription of genes related to metabolic activity; specifically in those related with the reduction of glucose transporters and increases in PTGS2, HAS2 and leptin receptors. Therefore, the differences between our results and those reported by Jaquiery et al. (2009), it may be attributed to the number of fetuses per pregnant ewes. Consequently, it may be inferred that pre-conception undernutrition has opposite effects in ewes with simple and twin pregnancies, being favorable in the cases of twin pregnancies.

There is not precise explanation in relation to why undernutrition before conception improved early fetal growth in the studied ewes. In this regard, Underwood et al. (2005) mention that early fetal growth is positively associated with the amniotic fluid volume, which is rich in nutrients (i.e. glucose, amino acids, proteins, lipids, lactate, electrolytes, polyamines, others) and growth factors with trophic effect on muscle tissue and intestines. Also Kwon et al. (2004) found that re-feeding in ewes with chronic undernutrition after conception promoted compensatory growth in fetuses due to the increase in amino acid and polyamine concentrations in amniotic fluid, as well as in fetal and maternal plasma. Therefore, if the vesicle is full of amniotic fluid, and was larger in RT ewes, it is likely that the higher fetal growth in RT ewes is due to the effect of postconception re-feeding after the pre-mating undernutrition period. The re-feeding in RT ewes could favor the direction of energetic substrates, amino acids and growth factors towards the fetus, which was reflected in a greater amniotic fluid volume and early fetal growth.

In the case of TR and RR ewes, fetal and vesicular growth at day 50 of pregnancy were not altered by undernutrition periods. These results suggest possible activation of physiological and metabolic adaptive mechanisms in the mother, fetus and/or placenta, which made it possible to compensate for nutritional deficits to which the twin fetuses of these ewes were exposed (MacLaughlin et al. 2005, Oliver et al. 2005, Belkacemi et al. 2010). It should also be taken into account that twin fetuses tend to present, in a natural way, intrauterine growth retardation problems, which is an adaptive mechanism that allows them to survive with lower energy expenditure, sacrificing their growth rate (van der Linden et al. 2013). This demonstrates that twin fetuses are programmed from the stage of early embryonic development to survive in pre-natal environments with low nutrient availability. On the other hand, the size of the cotyledons was not affected by the induced nutritional restriction in hairsheep ewes during the premating period and/or first third of gestation. These results were attributed to the fact that the measurements of these structures are in line with the early development of the placenta (Osgerby et al. 2002).

The birth weights of the twin lambs were altered by the pre-mating nutritional restriction, being higher in lambs from RT ewes than in lambs from control ewes (31\%). In contrast to these results, Smith et al. (2010) reported that the birth weight was not different between twin lambs born from well-fed or nutritionally restricted ewes from 28 days before to 7 days after conception. But there are reports in ewes with singleton gestation that are in line with birth weight results of this study (Jaquiery et al. 2012). In this regard, Van der Linden et al. (2013) mention that twin fetuses may have weights above normal at the end of ges- 
tation, when placentas show high efficiency to form fetal tissue, which may be due to increased placental functionality to transport amino acids to the fetus. This could explain the higher birth weights detected in the lambs born from RT ewes. On the other hand, birth weight results in TR and RR ewes are in agreement with previous studies indicating no effect of maternal nutritional restriction before and after (Jaquiery et al. 2012, Kleemann et al. 2015) or only after conception (Cleal et al. 2007) on the weights of newborn.

\section{CONCLUSIONS}

In hair ewes, nutritional restriction in the pre-mating and/or first third of gestation causes weight and body condition losses, which are recovered quickly by offering them a balanced diet for their physiological condition. However, when the undernutrition period occurs before the mating, there are alterations in the early fetal growth and birth weight of lambs in twin bearing ewes. The nutritional restriction of $40 \%$ of maintenance requirements during the pre-mating period followed by a well feeding with a diet formulated with $100 \%$ nutritional requirements during gestation, improves both early fetal growth and birth weight of lambs in twin bearing ewes.

\section{ACKNOWLEDGEMENTS}

To the UABC for the support granted for the development of this research within the framework of the 17th. Internal Call to Support Research Projects. Additionally, Ricardo Vicente and Yolanda Osorio thank Conacyt, Mexico, for the funding granted for the completion of their postgraduate studies in the ICA-UABC.

\section{LITERATURA CITADA}

Abdel-Mageed II, El-Gawad MHA (2015) Does parity and nutrition in early pregnancy affect viability of embryos in both Rahmani and Barki Egyptian Sheep? Asian Journal of Animal Veterinary Advances 10: 25-34.

Ali A, Hayder M (2007) Ultrasonographic assessment of embryonic, fetal and placental development in Ossimi sheep. Small Ruminant Research 73: 277-282.

Belkacemi L, Nelson DM, Desai M, Ross MG (2010) Maternal undernutrition influences placental-fetal development. Biology of Reproduction 83: 325-31.

Bloomfield FH, Oliver MH, Hawkins P, Holloway AC, Campbell M, Gluckman PD, et al. (2004) Periconceptional undernutrition in sheep accelerates maturation of the fetal hypothalamic-pituitary-adrenal axis in late gestation. Endocrinology 145: 4278-85.

Bloomfield FH, Spiroski AM, Harding JE (2013) Fetal growth factors and fetal nutrition. Seminars in Fetal and Neonatal Medicine 18: 118-123.

Boland MP, Lonergan P, O'Callaghan D (2001) Effect of nutrition on endocrine parameters, ovarian physiology, and oocyte and embryo development. Theriogenology 55: 1323-1340.

Cappelle ER, Filho SCV, Da Silva JFC, Cecon PR (2001) Estimativas do valor energético a partir de características químicas e bromatológicas dos alimentos. Revista Brasileira de Zootecnia 30: 1837-1856.

Chillard Y, Bocquier F, Doreau M (1998) Digestive and metabolic adaptations on ruminants to undernutrition, and consequences on reproduction. Reproduction Nutrition Development 38: 131-152.

Cleal JK, Poore KR, Boullin JP, Khan O, Chau R, Hambidge O, et al. (2007) Mismatched pre- and postnatal nutrition leads to cardiovascular dysfunction and altered renal function in adulthood. Proceeding of the National Academic Science of the United State of America 104: 9529-9533. 
Corner-Thomas RA, Hickson RE, Morris ST, Kenyon PR (2014) The influences of live weight and body condition score of ewe lambs from breeding to lambing on live weight of their singleton lambs to weaning. Small Ruminant Research 119: 16-21.

Fleming TP, Velazquez MA, Eckert JJ, Lucas ES, Watkins AJ (2012) Nutrition of females during the periconceptional period and effects on fetal programming and health of offspring. Animal Reproduction Science 130: 193-197.

Galvani DB, Pires CC, Wommer TP, Oliviera F, Santos MF (2010) Chewing patterns and digestion in sheep submitted to feed restriction. Journal of Animal Physiology and Animal Nutrition 94: e366-e373.

Grazul-Bilska AT, Johnson ML, Borowicz PP, Baranko L, Redmer DA, Reynolds LP (2013) Placental development during early pregnancy in sheep: effects of embryo origin on fetal and placental growth and global methylation. Theriogenology 79: 94-102.

Jaquiery AL, Oliver MH, Honeyfield-Ross M, Harding JE, Bloomfield FH (2012) Periconceptional undernutrition in sheep affects adult phenotype only in males. Journal of Nutrition and Metabolism ID 123610: $1-7$.

Jaquiery AL, Oliver MH, Rumball CWH, Bloomfield FH, Harding JE (2009) Undernutrition before mating in ewes impairs the development of insulin resistance during pregnancy. Journal of Obstetrics and Gynecology 114: 869-76.

Kleemann DO, Kelly JM, Rudiger SR, McMIllen IC, Morrison JL, Zhang S, et al. (2015) Effect of periconceptional nutrition on the growth, behavior and survival of the neonatal lamb. Animal Reproduction Science 160:12-22.

Kwon H, Ford SP, Bazer FW, Spencer TE, Nathanielsz PW, Nijland MJ, et al. (2004) Maternal nutrient restriction reduces concentrations of amino acids and polyamines in ovine maternal and fetal plasma and fetal fluids. Biology Reproductive 71: 901-908.

Lassoued N, Rekik M, Mahouachi M, Ben Hamouda M (2004) The effect of nutrition prior to and during mating on ovulation rate, reproductive wastage, and lambing rate in three sheep breeds. Small Ruminant Research 52: 117-125.

MacLaughlin SM, Walker SK, Roberts CT, Kleemann DO, McMillen IC (2005) Periconceptional nutrition and the relationship between maternal body weight in the periconceptional period and feto-placental growth in the sheep. The Journal of Physiology 565: 111-124.

Martin GB, Rodger J, Blache D (2004) Nutritional and environmental effects on reproduction in small ruminants. Reproduction Fertility Development 16: 491-501.

Morrison JL, Duffield JA, Muhihausler BS, Gentili S, McMillen IC (2010) Fetal growth restriction, catch-up growth and the early origins of insulin resistance and visceral obesity. Pediatric Nephrology 25: 669-677.

Muñoz C, Carson AF, McCoy MA, Dawson LER, O'Conell NE, Gordon AW (2008) Nutritional status of adult ewes during early and mid-pregnancy. 1 . Effects of plane of nutrition on ewe reproduction and offspring performance to weaning. Animal 2: 52-63.

NRC (1985) Nutrient Requirements of Sheep. National Academy Press, Washington, DC. 100p.

NRC (2007) Nutrient Requirements of Small Ruminants: sheep, goats, cervids, and new world camelids. National Academy Press, Washington, DC. 359p. 
Oliver MH, Hawkins P, Harding JE (2005) Periconceptional undernutrition alters growth trajectory and metabolic and endocrine responses to fasting in late-gestation fetal sheep. Pediatric Research 57: 591-598.

Osgerby JC, Wathes DC, Howard D, Gadd TS (2002) The effect of maternal undernutrition on ovine fetal growth. Journal of Endocrinology 173: 131-141.

Pisani LF, Antonini S, Pocar P, Ferrari S, Brevini TAL, Rhind SM, et al. (2008) Effects of pre-mating nutrition on mRNA levels of developmentally relevant genes in sheep oocytes and granulosa cells. Reproduction 136: 303-312.

Robertson SM, Clayton EH, Friend MA (2015) Reproductive performance of ewes grazing Lucerne during different periods around mating. Animal Reproduction Science 62: 62-72.

Rumball CWH, Bloomfield FH, Oliver MH, Harding JE (2009) Different periods of periconceptional undernutrition have different effects on growth, metabolic and endocrine status in fetal sheep. Pediatric Research 66: 605-613.

Rumball CWH, Harding JE, Oliver MH, Bloomfield FH (2008) Effects of twin pregnancy and periconceptional undernutrition on maternal metabolism, fetal growth and glucose-insulin axis function in ovine pregnancy. The Journal of Physiology 586: 1399-1411.

Russell AJF, Doney JM, Gunn RJ (1969) Subjective assessment of body fat in live sheep. The Journal of Agricultural Science 72: 451-454.

SAS (2004) User's guide statistics released 9.1. SAS Institute, SAS/STAT. 2nd Ed. SAS Institute, Inc. Cary, NC, USA.

Sejian V, Maurya VP, Naqvi SMK, Kumar D, Joshi A (2010) Effect of induced body condition score differences on physiological response, productive and reproductive performance of Malpura ewes kept in a hot, semiarid environment. Journal of Animal Physiology and Animal Nutrition 94: 154-61.

Smith NA, McAuliffe FM, Quinn K, Lonergan P, Evans ACO (2010) The negative effects of a short period of maternal undernutrition at conception on the glucose-insulin system of offspring in sheep. Animal Reproduction Science 121: 94-100.

Underwood MA, Gilbert WM, Sherman MP (2005) Amniotic fluid: not just fetal urine anymore. Journal of Perinatology 25: 341-348.

Van der Linden DS, Sciascia Q, Sales F, McCoard SA (2013) Placental nutrient transport is affected by pregnancy Rank in sheep. Journal of Animal Science 91: 644-653. 
